\title{
INFLUENCE OF THE BUILDING GEOMETRY ON ENERGY EFFICIENCY OF TIMBER-GLASS BUILDINGS FOR DIFFERENT CLIMATIC REGIONS
}

\author{
Miroslav Premrov ${ }^{1}$ Maja Žigart ${ }^{1}$ Vesna Žegarac Leskovar ${ }^{1^{*}}$ \\ ${ }^{1}$ University of Maribor, Faculty of Civil Engineering, Transportation Engineering and Architecture, Slovenia
}

The presented study is focused into examination of the building shape influence on the annual energy need for heating and cooling by taking into account climate data for six European cities located in different climatic regions. The research is performed on timber-glass box-house models parametrically varying building aspect ratio (L/W) and number of storeys (single- and two-storey), while the glazing - to - wall area ratio for southern façade is kept constant for all treated models ( $A G A W=35 \%)$. The influence of the mentioned parameters on the annual energy need is thoroughly analysed and leads to completely different conclusions drawn for cold and warm climate conditions.

According to the presented results the recommendation for cold climate conditions is to design two-storey houses rather than single-storey ones. Additionally, the increasing aspect ratio shows a positive influence on the energy need reduction. In the case of warm climate conditions the findings are almost opposite to those for cold climates. The total energy need consist predominantly of data for cooling, whereby the energy need increases with the increasing aspect ratio. On behalf of specifics related to warm climate a further study was conducted for Athens with an additional examination of the building components with higher thermal transmittance $(U)$. The results of the research for Athens show that designers are practically free to choose between single-storey or two-storey buildings with no significant impact on the building energy behaviour.

The main output of the current study is to offer designers general information on energy-efficient design parameters for single-family timber-glass buildings under influence of different European climatic conditions.

Key words: Building geometry, Energy demand, Timber-glass buildings, Climatic impacts

\section{INTRODUCTION}

Designing nearly zero-energy buildings is a goal in many European countries; numerous studies have therefore emerged to find a solution for designing buildings with high energy performance. The first step in designing an energy-efficient building should be a rational passive design offering good thermal and living comfort, even without active systems. The main focus should be laid on climate conditions, orientation of the building, building geometry, glazing size and characteristics of the thermal envelope. We should also consider environmental issues by observing the whole life cycle of buildings and by using recyclable materials which need less energy for production. The measures taken to save energy vary in nature, and the decision maker is required to establish an optimal solution, taking into account multiple and usually competitive objectives such as energy consumption, financial costs, environmental performance, renewable energy utilization, etc., Diakaki et al. [01].

As a natural raw material requiring minimal energy input into the process of becoming construction material, timber shows indisputable environmental excellence. It certainly represents one of the best choices for energy-efficient construction since it also functions as a material with good thermal transmittance properties if compared to other construction materials. On the other hand, the use of glazing in buildings has always contributed to the feeling of openness and a better daylight situation of interiors. Although characterized by weak thermal properties in the past, glass has been gaining an ever greater significance as a building material due to its improved thermal, optical and strength properties, resulting from years of development, Wurm [02].

The features of both building materials presented above lead to the development of a new type of structures, i.e. timber-glass houses (see Figure 1), suitable for the construction of energy-efficient buildings where an optimal proportion and appropriate orientation of the glazing surfaces play an important part due to exploitation of solar radiation as a source of renewable energy within the passive use of energy for heating.

To obtain an increased share of solar gains useful for passive heating of the building the glazing areas are mostly placed on the south-oriented building envelope. However, to assure better and evenly distributed natural illumination in the building it is convenient to place some openings also on other parts of the building envelope. The geometry of the building is thus utterly significant; along with the building's self-shading it can essentially affect solar gains in the heating and cooling periods, with prevention against overheating in the latter. It is therefore of utmost importance to design a building in an optimal way according to its macro and micro-location, climate conditions, materials to be used, etc. 

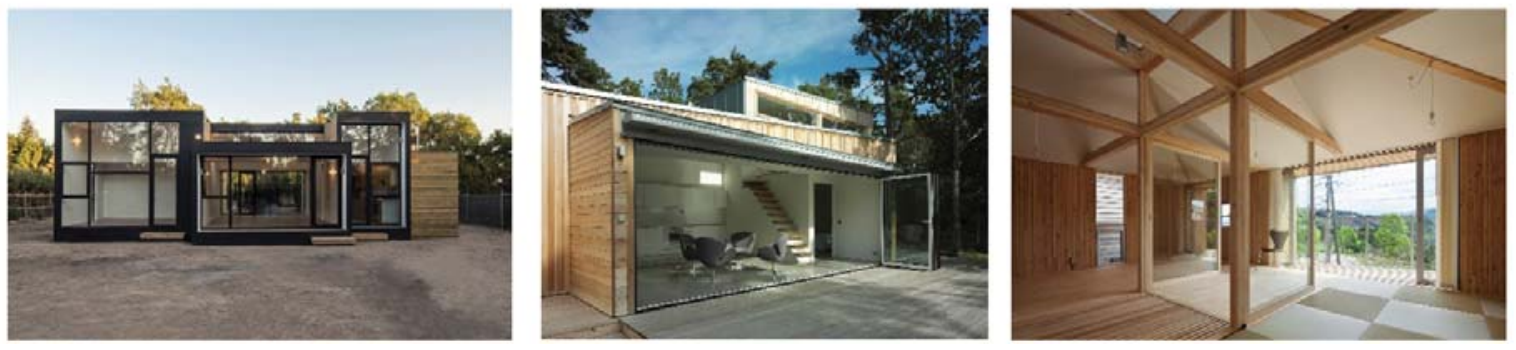

Figure 1: Example-set of timber-glass houses with the enlarged glazing size [03,04, and 05]

Numerous studies have investigated the effect of building geometry on the energy performance. Depecker et.al. [06] pointed to a strong correlation between the final energy use and the shape of the building witnessed in colder climates. Albatici and Passerini [07] analysed the relationship between the shape and the energy need in different climates in France and Italy. Their findings show that compactness should be looked for in colder climates, though it is not relevant in mild and sunny climates. Both studies have analysed the shape factor $\left(F_{S}=A / V\right)$ of buildings which is defined as the ratio between the envelope surface $(A)$ and the building volume $(V)$. Many parameters exert influence on the shape factor of the building, with the most important one being a dynamic form (L, T or U-shapes have higher values of the shape factor than rectangular areas). As schematically presented in Fig. 2b-2c, in buildings with rectangular shapes, the shape factor also depends on the building's horizontal and vertical dimensions and is generally higher in single-storey buildings as compared to multi-storey buildings, with the same useful floor area.

Similarly, the study by Ratti et.al. [08] also suggested that a cold climate may increase the impact of the building shape on the energy need. An extensive study presented in Danielski et.al. [09] analysed five existing apartment buildings for twelve different scenarios; three thermal envelope scenarios and four climate zones in Sweden. It was concluded that the impact of the shape factor was reduced with warmer climates and ceased with the average outdoor temperature ranging from $110^{\circ} \mathrm{C}$ to $140^{\circ} \mathrm{C}$, depending on the thermal envelope properties of the buildings. Rodrigues et al. [10] analysed six geometry-based building indices to determine their adequacy in eight different climate regions in Europe. The results show that geometry-based indices correlate with the buildings' thermal performance, according to specific climate regions and also to building design software tools.

Ling et al. [11], Inanici and Demirbilek [12] and Chiras [13] numerically analysed another geometrical parameter of buildings, the building aspect ratio $(A R=L / M)$, which is defined as a ratio between the building's equatorial-facing façade length $(L)$ and lateral façade width (W), see Figure 2a. As stated in a parametric study [12] the ideal aspect ratio for rectangular shaped houses in cold climates ranges from 1.3 to 1.5. However, Ling et.al. [11] suggest that an ideal building shape for hot and humid climates has a $1: 1$ ratio of the façade width $(W)$ and length $(L)$.

Hemsath and Bandhosseini [14] presented a methodology to evaluate the form of the building in order to compare the energy consumption of the building's geometric and material variations. The results indicate that the horizontal (aspect ratio) and vertical geometric proportion as well as building material characteristics have an impact on the building energy use whereby the impact strength depends on the location of the building. In the study of Aksoy and Inalli [15] the impact of the building shape and orientation on the energy demand for heating is investigated for cold Turkish regions. It follows that a square shape brings more advantages, and the most suitable orientation angles prove to be $0^{\circ}$ and $80^{\circ}$ for buildings having aspect ratios 2 and 0.5 .

With the exception of [10], the majority of the above mentioned studies mostly deal with the influence of geometric parameters for certain building types in certain climatic conditions which are usually limited solely to one country or even to only one climate region. To assess to what extent building geometry may influence the building energy efficiency in different European regions, the current study analyses twelve differing models of timber-glass single-family houses located in six European cities of different geographical latitudes, longitudes and elevations. The locations are selected intentionally, in order to encompass different climatic conditions of each particular region such as air temperature, solar radiation potential along with the apparent position of the sun determined by altitude and azimuth, etc. With respect to the fact that the total building energy use is influenced by climate conditions during different seasons and according to EN ISO 13790 [16] we should take into account the energy need for heating $(\mathrm{Qh})$ and cooling $(\mathrm{Qc})$ as well as their sum ( $Q h+Q c)$ to get better insight into the annual energy behaviour of the building.

The first, theoretical part of the paper, briefly describes the present research containing basic principles of energy flows in buildings considering the influence of different variable parameters, such as glazing size and building shape on the energy performance of buildings. The second part of the paper consists of an extensive parametric numerical analysis of the building's varying shape with the aspect ratio and its impact on the energy flows through the building skin within six different macroclimatic zones in Europe. 
a)

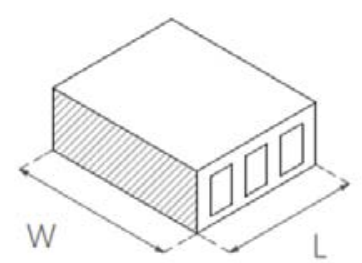

Lateral facade width

\begin{abstract}
Equatorial-facing facade length
\end{abstract}

b)

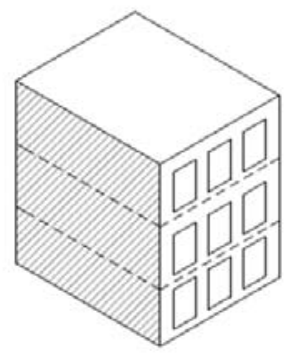

Multi-storey building (smaller Fs - smaller envelope surface)

Figure 2: Schematic presentation of the building aspect ratio (a) and a differing shape factor for two different types of rectangular buildings $(b-c)$

The submitted paper is a systematic upgrade of the numerical study [17] where a parametric analysis is carried out for eight different building shapes, i.e. square, rectangular, L, T and U, placed in three different climate conditions (Ljubljana, Munich and Helsinki) with the three-layer insulating glass placed only in the south façade while the ground floor area $\left(A=81 \mathrm{~m}^{2}\right)$ and the heated volume $\left(V=243 \mathrm{~m}^{3}\right)$ remain constant. In the presented study we extended the analysis from a single-storey house with $A=81 \mathrm{~m}^{2}$ in [17] to two-storey buildings with $A=81 \mathrm{~m}^{2}$ for each storey, in addition to the analysis of single-storey houses with $A=162 \mathrm{~m}^{2}$ in order to compare the energy behaviour of two-storey residential buildings with single-storey ones having the same total floor area. The study was furthermore extended for rectangular building shapes in warm climate conditions (Athens, Madrid) which were not analysed in [17].

The findings from the presented study can result in optimal design solutions for single and two storey timber-glass houses with a constant floor area and a varying building aspect ratio in six different European locations with cold, moderate and warm climates. The main benefit goes to general findings to be linked with a set of basic guidelines providing architects with a tool for a quick estimation of the energy performance of timber-glass buildings, designed in different shapes, in one or two storeys.

\section{ENERGY BALANCE OF BUILDINGS}

Energy-efficient building design requires a careful balance of energy consumption, energy gain and energy storage. A basic design principle integrates the building components into a system taking maximum advantage of the building's environment, its climatic conditions and available renewable energy sources. The use of contemporary active technical systems exploiting renewable energy is therefore strongly advised. The occupants play an important role in the system of energy-efficient buildings, since only with proper use can the buildings' energy balance reach a level planned by the engineers.
Energy efficiency of buildings according to EN ISO 13790 [16] calls for consideration of the energy need for heating (Qh) and cooling (Qc). A building is therefore analysed as a thermal system with a series of heat flows and energy balance consisting of the transmission heat losses $(\mathrm{Qt})$, ventilation heat losses $(\mathrm{Qv})$, internal heat gains $(\mathrm{Qi})$ and solar heat gains (Qs), as seen in Szokolay [18] and schematically presented in Figure 3.

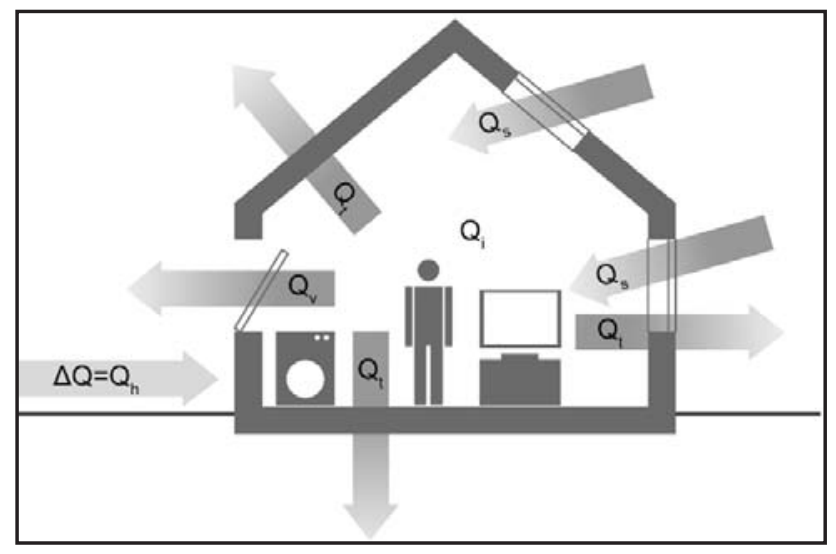

Figure 3: Scheme of energy flows in a building typical of the cold period scenario [19]

In the heating period the energy losses $\left(Q_{L}\right)$ in buildings consist of a sum of the transmission heat losses $\left(Q_{T}\right)$ and ventilation heat losses $\left(Q_{v}\right)$ caused by air exchange between the building and its surroundings, in the form of:

$$
Q_{L}=Q_{T}+Q_{V}
$$

The heat gains $\left(Q_{G}\right)$ in buildings for the heating period are a sum of solar heat gains caused by solar radiation $\left(Q_{S}\right)$ and internal heat gains generated inside the building $\left(Q_{1}\right)$, in the form of:

$$
Q_{G}=Q_{S}+Q_{I}
$$


The amount of energy required for heating $\left(Q_{H}\right)$ equals the difference between the sums total of heat losses $\left(Q_{L}\right)$ and heat gains $\left(Q_{G}\right)$ of the building, where the heat gains are, according to EN ISO 13790 [16], multiplied with the utilization factor $\eta_{G}$, in the form of:

$$
\begin{aligned}
& Q_{H}=Q_{L}-\eta_{G} \cdot Q_{G} \\
& \eta_{G}=\left(1-\left(Q_{G} / Q_{L}\right)^{5}\right) /\left(1-\left(Q_{G} / Q_{L}\right)^{6}\right)
\end{aligned}
$$

All calculated values for energy are usually presented as normed per $1 \mathrm{~m}^{2}$ of usable floor area (ATFA), in the forms of:

$$
\begin{aligned}
Q_{h} & =Q_{H} / A_{T F A} \\
Q_{t} & =Q_{T} / A_{T F A} \\
Q_{s} & =Q_{S} / A_{T F A} \\
Q_{c} & =Q_{C} / A_{T F A}
\end{aligned}
$$

As they are nearly independent of the shape of the building at a constant usable floor area $\left(A_{T F A}\right)$ the ventilation losses and the internal heat gains in our study are assumed to be constant. Thus the change of the energy need for heating normed per $1 \mathrm{~m}^{2}$ of usable floor area $\left(\Delta Q_{h}\right)$ results from Equation (3a), in the approximate form of:

$$
\Delta Q_{h} \approx Q_{t}-\eta_{G} \cdot Q_{s}
$$

The transmissions heat losses $Q_{t}$ normed per $1 \mathrm{~m}^{2}$ of usable floor area are calculated for every building element of the heat-exchanging envelope using:

$$
Q_{t}=Q_{T} / A_{T F A}=A \cdot U \cdot f_{T} \cdot G_{t} / A_{T F A}
$$

where $A$ is the building envelope area, $U$ is the building envelope thermal transmittance, $f_{T}$ is the reduction factor for the reduced temperature difference and $G_{t}$ is the temperature difference time integral (heating degree hours) which mostly depends on the climate conditions in the heating period. Respecting Equation (6), it is evident that an increasing envelope area $(A)$ strongly influences the transmission losses, which leads to a conclusion that multi-storey buildings generally have lower transmission losses than single-storey buildings (Figure 2a) with the same ground floor area. This fact will undergo a thorough analysis in Section 3.

The solar heat gains $Q_{s}$ normed per $1 \mathrm{~m}^{2}$ of usable floor area are calculated using:

$$
Q_{s}=Q_{S} / A_{T F A}=r \cdot g \cdot A_{w} \cdot G / A_{T F A}
$$

where $r$ is the reduction factor taking into account the frame-to-window-area ratio, shading, dirt on the glazing and the tilted incidence angle of radiation through the glazing; $g$ is the degree of solar energy transmitted through the glazing normal to the irradiated surface, $A_{w}$ is the window area (rough opening) and $G$ is the total radiation during the heating period. It has been justified in several existing studies that glazing surfaces, if oriented towards the equator where the solar potential is the highest, enable solar radiation to enter the building. The parameter which can significantly influence the amount of solar gains and consequently the total energy need for heating and cooling is the glazing-to-wall area ratio ( $A G A W$ ) of the façade described as the ratio between the total area of the glazing on the facade $\left(A_{g s}\right)$ and the total area of the wall $\left(A_{\text {wall }}\right)$ :

$$
A G A W=A_{g s} / A_{\text {wall }}
$$

The influence of the $A G A W$ value on the energy need is analysed in details using the climate conditions for Ljubljana in Žegarac Leskovar and Premrov [20]. The presented calculations demonstrated that the glazing size of $A G A W=35 \%$ placed in the south façade of passive timber-glass houses leads to minimum values of the total annual energy need for heating and cooling $\left(Q_{h}+Q_{c}\right)$. The value of $r$ in Equation (7) can be influenced also by the building geometry. In the early design stage, when determining the building geometry which can be either compact (square, rectangular) or dynamic (L, U, T-shape), it is important to consider direct solar penetration through the glazing in the south façade which significantly depends also on the so-called self-shading, parametrically analysed in [17].

In the presented research the study from [20] was extended and upgraded in [17] where it was concluded that the value of $A G A W=35 \%$ is the optimal size of glazing placed in the south façade of the passive type of timber-glass buildings in basically every climate condition considered (Ljubljana, Munich and Helsinki) and any shape of the building.

\section{NUMERICAL STUDY}

\section{Simulation model}

For calculations of energy flows and energy needs for heating and cooling the planning tool PHPP 8 [21] was used based on EN ISO 13790 [16] which shows high levels of precision and accuracy in calculating energy balances.

\subsection{Building geometry}

The presented numerical research is based on a case study of a box model of 3-metre-high single and two-storey houses built in the prefabricated passive timber-frame structural system with the glazing installed only in the south façade of the building. Three different groups of rectangular models are analysed (Figure 4):

- Model group A: single-storey models with a constant occupied floor area $\left(A_{T F A}=81 \mathrm{~m}^{2}\right)$, a constant heated volume $\left(V=243 \mathrm{~m}^{3}\right)$ and a varying aspect ratio $(A R)$ ranging from 0.83 to 1.69 . 
- Model group B: single-storey models with a doubled constant occupied floor area $\left(A_{T F A}=162 \mathrm{~m}^{2}\right)$, a constant heated volume $\left(V=486 \mathrm{~m}^{3}\right)$ and a varying aspect ratio $(A R)$ ranging from 0.83 to 1.69 .

- Model group C: two-storey models with a doubled basic occupied floor area of each storey $\left(A_{T F A}=81 \mathrm{~m}^{2}\right)$, a constant heated volume of each storey $\left(V=243 \mathrm{~m}^{3}\right)$ and a varying aspect ratio $(A R)$ ranging from 0.83 to 1.69 .

The main aim of the research is to vary the architectural geometry of the building and consequently its building aspect ratio $(A R=L / W)$ and the shape factor $\left(F_{S}\right)$ whose values are parametrically changed with various floor plan models. The building shape factor values vary parametrically from 1.01 for the building shape 1 of Model C (two-storey building) to 1.50 for the building shape with the highest aspect ratio in Model A (single-storey building), see Figure 4. A comparison of Model groups B and $\mathrm{C}$ shows that two-storey buildings generally have an evidently lower building shape factor $\left(F_{S}\right)$ than single-storey buildings with the same floor area at the same aspect ratio.

\section{Characteristics of the building envelope}

The exterior walls are constructed using a timber-frame macro-panel system with timber class C22. The exterior walls and the roof are considered to be meeting the re- quirements of the passive house standard with $U=0.10$ $\mathrm{W} / \mathrm{m}^{2} \mathrm{~K}$, the bottom plate thermal transmittance is 0.135 $W / m^{2} K$. However, the models located in Athens were additionally calculated also for the walls and roof with $\mathrm{U}$-values of $0.20 \mathrm{~W} / \mathrm{m}^{2} \mathrm{~K}$ and for the bottom plate with $\mathrm{U}$-value of $0.25 \mathrm{~W} / \mathrm{m}^{2} \mathrm{~K}$.

\section{Characteristics of glazing}

As seen in Figure 4, only the south-oriented windows were chosen for easier comparison of the solar gains in different climates. The percentage of glazing area in the south façade (AGAW) was kept constant at the value of $35 \%$ which was chosen based on the findings in the study by Žegarac Leskovar and Premrov [20], where the optimal glazing size on the south façade with a passive standard of external walls Uwall $=0.10 \mathrm{~W} / \mathrm{m}^{2} \mathrm{~K}$ was $A G A W=35 \%$, for climate conditions in Ljubljana. The glazing sizes on the south façade were therefore influenced by the building's width and aspect ratio.

The window insulating glazing (Unitop 0.51-52 Uniglas) with three layers of glass, two low-emissive coatings and krypton in the cavities for a normal configuration of $4 \mathrm{E}-12-4-12-\mathrm{E} 4$, is installed. The glazing configuration with a g-value of $52 \%$ and $U g=0.51 \mathrm{~W} / \mathrm{m}^{2} \mathrm{~K}$ assures a high level of heat insulation and light transmission. The $\mathrm{U}$-value of the window frame is $\mathrm{Uf}=0.73 \mathrm{~W} / \mathrm{m}^{2} \mathrm{~K}$.

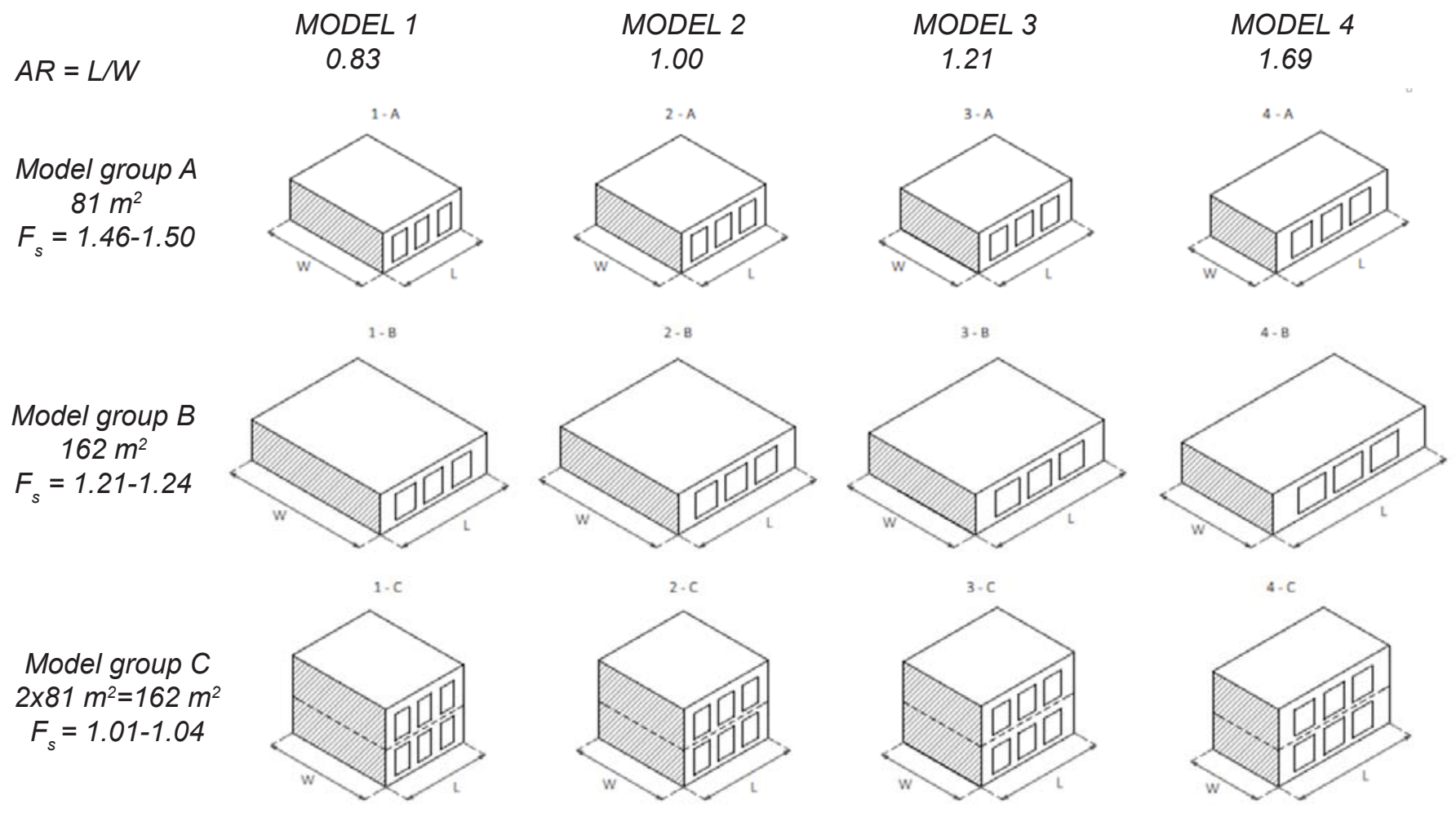

Figure 4: Schematic presentation of the analysed house models 


\section{Climate data}

The study analyses the energy performance for different European climatic regions. The selected cities of Ljubljana, Helsinki, Munich, London, Athens and Madrid are all places with various average air temperatures and solar radiation. Weather information from Meteonorm [22] with temperature data for the period of 2000-2009 and radiation data for the period of 1991-2010 was used for calculations. The above mentioned data are presented in Table 1.

For calculation of the solar gains in the heating period only (Equation 7) is of special importance for the value of $G$. The value for the most northwardly located city in the study (Helsinki) is higher $\left(452 \mathrm{kWh} / \mathrm{m}^{2}\right)$ than that for Ljubljana $\left(407 \mathrm{kWh} / \mathrm{m}^{2}\right)$, but it should be taken into account that the annual heating period in Helsinki (232.550 days) is much longer than in Ljubljana (183.799 days), which will in consequence lead to significantly higher transmission losses, defined by using Equation (6).

\section{Results}

Calculated results for geometrical characteristics of the building envelope and solar gains $\left(Q_{S}\right)$ through $1 \mathrm{~m}^{2}$ of glazing for all analysed twelve models are listed in Table 2. They are important for our further calculations and explanations. The results for $Q_{S}$ in the heating period are calculated using Equation (7) with the values for $G$ from the last row in Table 1, and the g value of 0.52 .

In reference to average solar gains of the analysed models (groups A, B and C) for all treated locations (Table 2), the average amount transmitted through $1 \mathrm{~m}^{2}$ of vertical south-oriented glazing surface in the heating season period proves to be the lowest in Athens, with an average value of $59.83 \mathrm{kWh}$ and the highest in Munich, with an average value of $208.19 \mathrm{kWh}$. The size of the southern façade and consequently that of transparent areas for all model groups ( $A$, B and $C$ ) demonstrate a significant increase at a higher aspect ratio (from Model 1 to Model 4).

The calculated results for the transmission losses through the building thermal envelope surface areas normed per $1 \mathrm{~m}^{2}$ of usable floor area $\left(Q_{t}\right)$, using Equation (6), are graphically presented in Figure 5 . They encompass all the single and two-storey house models for all of the six selected locations at the thermal transmittance of walls $U=0.10 \mathrm{~W} / \mathrm{m}^{2} \mathrm{~K}$.

As seen above, the transmissions losses are the highest for Helsinki and the lowest for Athens for all selected house models. Additionally, we can observe that the increasing aspect ratio and consequently the shape factor of the building have a stronger influence in cities lying northwardly (Helsinki and Munich) than in southern locations (Athens and Madrid). Higher transmission losses at the increasing aspect ratio appear due to the increase of the building envelope, i.e. particularly to the enlargement of the glazing surfaces installed in the main/southern façade which are the weakest point of the building envelope in regard to the $U$-value. However, the differences between the treated cities are in accordance with the difference of average air temperatures in the heating season, which in turn means the strongest influence of the growing aspect ratio for the coldest regions.

It can be claimed that the transmission losses considered per $1 \mathrm{~m}^{2}$ of usable floor area are generally higher for the single-storey house models (Model group A) than for the two-storey ones (Model group C), which is linked to the ratio between the total building envelope surface and the usable floor area (see Table 2). The difference between the single-storey (Model group B) and two-storey models (Model group C) with the same usable floor area $\left(162 \mathrm{~m}^{2}\right)$ are very small and decreases with the location to the south where in general the transmission losses are lower due to a higher average air temperature.

Table 1: Climate conditions of the selected cities

\begin{tabular}{|c|c|c|c|c|c|c|}
\hline City & Ljubljana & London & Munich & Helsinki & Athens & Madrid \\
\hline Elevation $(\mathrm{m})$ & 299 & 18 & 529 & 12 & 147 & 662 \\
\hline $\begin{array}{c}\text { Latitude } \\
\text { Longitude }\end{array}$ & $\begin{array}{c}46.067 \\
14.517\end{array}$ & $\begin{array}{c}51.507 \\
-0.128\end{array}$ & $\begin{array}{c}48.133 \\
11.700\end{array}$ & $\begin{array}{c}60.220 \\
25.000\end{array}$ & $\begin{array}{c}38.950 \\
23.700\end{array}$ & $\begin{array}{c}40.417 \\
-3.704\end{array}$ \\
\hline $\begin{array}{c}\text { Average annual } \\
\text { temperature }\left({ }^{\circ} \mathrm{C}\right)\end{array}$ & 11.3 & 13.1 & 9.3 & 6.6 & 18.6 & 16.3 \\
\hline $\begin{array}{c}\text { Average annual temperature in the } \\
\text { heating period }\left({ }^{\circ} \mathrm{C}\right)\end{array}$ & 4.5 & 8.3 & 4.0 & 1.6 & 9.0 & 8.0 \\
\hline Length of the heating period (days/an.) & 183.799 & 170.218 & 211.464 & 232.550 & 65.611 & 133.689 \\
\hline $\begin{array}{c}\text { Total annual solar radiation } \mathrm{G} \text { on the south } \\
\text { vertical surface }\left(\mathrm{kWh} / \mathrm{m}^{2}\right)\end{array}$ & 969 & 837 & 999 & 926 & 1100 & 1280 \\
\hline $\begin{array}{c}\text { Total solar radiation } \mathrm{G} \text { on the south verti- } \\
\text { cal surface in the heating period }\left(\mathrm{kWh} / \mathrm{m}^{2}\right)\end{array}$ & 407 & 289 & 517 & 452 & 151 & 436 \\
\hline
\end{tabular}


Table 2: Calculated results for geometrical characteristics of the building envelope, solar gains $\left(Q_{S}\right)$ through $1 m^{2}$ of glazing

\begin{tabular}{|c|c|c|c|c|c|c|c|c|c|c|c|c|}
\hline MODELS & $1-\mathrm{A}$ & $2-\mathrm{A}$ & $3-A$ & $4-\mathrm{A}$ & $1-B$ & $2-B$ & $3-B$ & $4-B$ & $1-C$ & $2-C$ & $3-C$ & $4-C$ \\
\hline $\begin{array}{c}\text { Usable } \\
\text { floorarea }\left(m^{2}\right)\end{array}$ & 81 & 81 & 81 & 81 & 162 & 162 & 162 & 162 & 162 & 162 & 162 & 162 \\
\hline L/W & 0.82 & 1.00 & 1.21 & 1.69 & 0.82 & 1.00 & 1.21 & 1.69 & 0.82 & 1.00 & 1.21 & 1.69 \\
\hline \multicolumn{13}{|c|}{ Areas of thermal envelope $\left(\mathrm{m}^{2}\right)$} \\
\hline 1. exterior wall & 148.6 & 146.6 & 146.0 & 148.4 & 204.8 & 201.8 & 201.0 & 204.0 & 273.9 & 270.0 & 268.9 & 273.4 \\
\hline 2. roof / ceiling & 97.9 & 97.8 & 97.9 & 98.5 & 185.6 & 185.5 & 185.6 & 186.2 & 97.9 & 97.8 & 97.9 & 98.5 \\
\hline 3. floor slab & 97.9 & 97.8 & 97.9 & 98.5 & 185.6 & 185.5 & 185.6 & 186.2 & 97.9 & 97.8 & 97.9 & 98.5 \\
\hline 4. windows & 12.8 & 14.0 & 15.4 & 18.3 & 17.6 & 19.4 & 21.4 & 25.2 & 23.5 & 25.9 & 28.5 & 33.7 \\
\hline 4.1 glass & 9.29 & 10.40 & 11.64 & 14.20 & 13.51 & 15.10 & 16.89 & 20.28 & 16.77 & 18.86 & 21.18 & 25.81 \\
\hline $\begin{array}{c}\text { Total building } \\
\text { envelope area }\left(\mathrm{m}^{2}\right)\end{array}$ & 357.2 & 356.2 & 357.2 & 363.7 & 593.6 & 592.2 & 593.6 & 601.6 & 493.2 & 491.5 & 493.2 & 504.1 \\
\hline Build. env. /floor a. & .410 & 4.398 & 4.410 & 4.490 & 3.664 & 3.656 & 3.664 & 3.714 & 3.044 & 3.034 & 3.044 & 3.112 \\
\hline $\begin{array}{l}\text { Non-transp. env./ } \\
\text { floor a. }\end{array}$ & 4.252 & 4.225 & 4.220 & 4.264 & 3.556 & 3.536 & 3.532 & 3.558 & 2.899 & 2874 & 2.869 & 2.904 \\
\hline Windows/floor a. & 0.158 & 0.173 & 0.190 & 0.226 & 0.109 & 0.120 & 0.132 & 0.156 & 0.145 & 0.160 & 0.176 & 0.208 \\
\hline \multicolumn{13}{|c|}{ QS/glass area $\left(\mathrm{kWh} / \mathrm{m}^{2} \mathrm{a}\right)$} \\
\hline Ljubljana & 162.22 & 162.75 & $\begin{array}{c}163.2 \\
3\end{array}$ & 164.05 & 163.85 & 164.27 & $\begin{array}{c}164.6 \\
2\end{array}$ & 165.19 & 161.73 & 162.28 & 162.86 & 163.66 \\
\hline Munich & 206.78 & 207.39 & $\begin{array}{c}207.9 \\
9\end{array}$ & 208.99 & 208.72 & 209.23 & $\begin{array}{c}209.7 \\
3\end{array}$ & 210.36 & 206.15 & 206.83 & 207.53 & 208.53 \\
\hline Helsinki & 184.28 & 184.78 & $\begin{array}{c}185.1 \\
4\end{array}$ & 185.81 & 185.70 & 185.99 & $\begin{array}{c}186.2 \\
9\end{array}$ & 186.74 & 183.91 & 184.40 & 184.86 & 185.52 \\
\hline Athens & 59.31 & 59.54 & 59.79 & 60.08 & 60.05 & 60.19 & 60.38 & 60.60 & 59.10 & 59.34 & 59.59 & 59.94 \\
\hline London & 116.00 & 116.68 & $\begin{array}{c}116.9 \\
2\end{array}$ & 117.49 & 117.36 & 117.59 & $\begin{array}{c}117.8 \\
6\end{array}$ & 118.20 & 115.99 & 116.36 & 116.68 & 117.21 \\
\hline Madrid & 172.23 & 172.85 & $\begin{array}{c}173.4 \\
5\end{array}$ & 174.40 & 174.14 & 174.67 & $\begin{array}{c}175.1 \\
0\end{array}$ & 175.74 & 171.69 & 172.36 & 173.01 & 173.97 \\
\hline
\end{tabular}




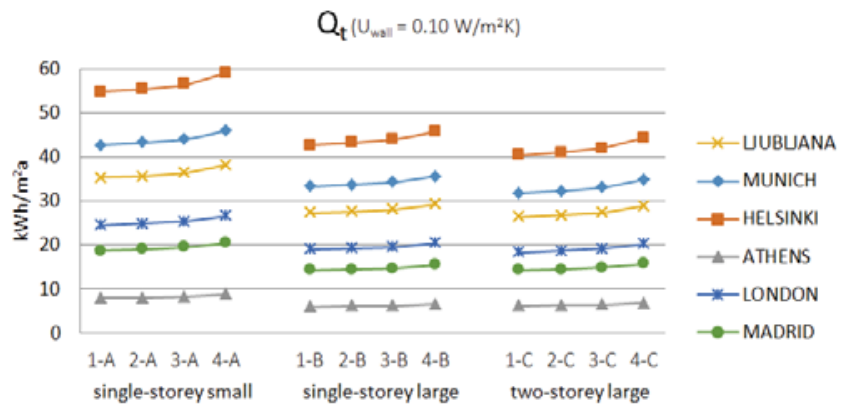

Figure 5: Calculated transmissions losses for all models; $U=0.10 \mathrm{~W} / \mathrm{m}^{2} \mathrm{~K}$

However, it is interesting to compare the envelope size of model groups $\mathrm{B}$ and $\mathrm{C}$, where the $\mathrm{B}$ models have the largest total building envelope surface and the $C$ models have the largest window areas (see Table 2).

The calculated results for the solar gains normed per 1 $\mathrm{m}^{2}$ of usable floor area $\left(Q_{s}\right)$ in the heating period using Equation (7) are graphically presented in the same way in Figure 6.

Interestingly, the solar gains for the heating period are always the highest for Munich and Helsinki. The reason lies in the fact that the heating period in these two cities (see Table 1) is significantly longer than that in Athens or Madrid, for example, with significantly higher total annual solar radiation. In the latter two cities the solar radiation is particularly high in the summer, which seriously impacts the energy need for cooling. Additionally, it can be observed that the solar gains of single-storey models with $162 \mathrm{~m}^{2}$ (Model B) are always evidently lower than those of single-storey models with $81 \mathrm{~m}^{2}$ (ModelA), provided that the valuesareconsideredper $1 \mathrm{~m}^{2}$ of usable floor area. In principle, the solar gains for certain locations depend mostly on the inclination, orientation, type and size of glazing. Comparing only the results for models with the same usable floor area of $162 \mathrm{~m}^{2}$ (Models $\mathrm{B}$ and $\mathrm{C}$ ) and a fixed $A G A W$ value of south-oriented glazing suggests a conclusion that the solar gains in all cities are higher for Models C (two-storey building) due to a larger glazing surface. This observation might lead to the next finding which states that in the case of designing a single-storey house, the south-oriented glazing share $(A G A W)$ should be larger than in two-storey house designs in order to exploit the positive contribution of solar radiation.

Respecting the given results for the transmission losses $\left(Q_{t}\right)$ and solar gains $\left(Q_{s}\right)$ in addition to the feasibility of treating the energy need for heating as an approximate difference between the transmission losses and the solar gains (Equation 5), it is now possible to analyse the results for the annual energy need for heating $\left(Q_{h}\right)$ and the annual energy need for cooling $\left(Q_{c}\right)$.

In view of the already presented findings for $Q t$ and $Q s$ and the conclusions given, the results for the annual energy demand are presented separately in three selected groups of cities with similar climate conditions and similar calculated energy behaviour according to the

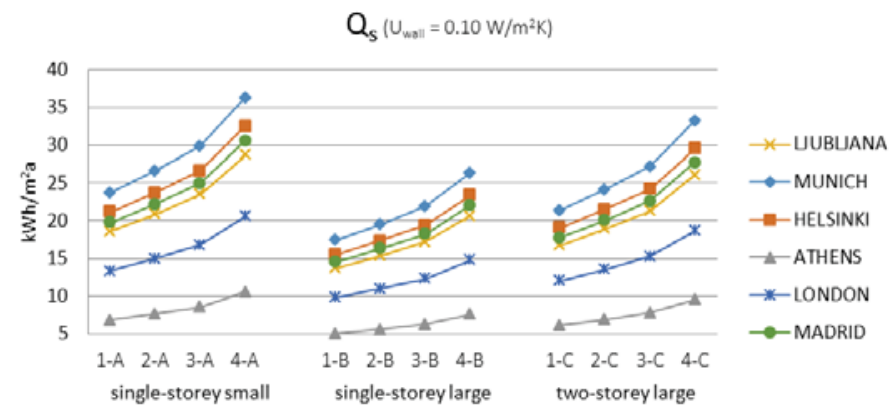

Figure 6: Calculated solar gains in the heating period for all models, with $U=0.10 \mathrm{~W} / \mathrm{m}^{2} \mathrm{~K}$

increasing aspect ratio; for climates with the strongest winter conditions (Helsinki and Munich) in Figure 7, for southern locations (Athens and Madrid) in Figures 8 and 9 and for "intermediate climates" (Ljubljana and London) in Figure 10. An interesting point is also observed in the comparison of the sum total of the annual energy need for heating and cooling $\left(Q_{\text {total }}=Q_{h}+Q_{c}\right)$.

It can be claimed that the total energy need $\left(Q_{\text {total }}\right)$ for Helsinki and Munich mostly depends on the energy need for heating $\left(Q_{h}\right)$. The energy need for cooling can be almost neglected. All in all, it can be estimated that the total energy need (Qtotal) decreases nearly linearly with the increasing aspect ratio. Furthermore, on condition it is considered per $1 \mathrm{~m}^{2}$ of usable floor area, the energy need is generally higher for single-storey house models (Model group A) than for two-storey ones (Model group C). The difference is more evident for Helsinki with stronger winter conditions and a longer heating period (see data from Table 1). Comparing solely models with the same occupied floor area of $162 \mathrm{~m}^{2}$ leads us to the observation that the two-storey model (Model group C) has essentially lower energy need for heating than the single-storey model (Model group B) and can therefore be treated as a more energy-efficient one.

Two cities were analysed (Athens and Madrid) as representatives of warm climate conditions. The results for the transmissions losses and solar gains were already graphically presented in Figures 5 and 6 . The results for $Q_{h}, Q_{c}$ and $Q_{\text {total }}$ for models with the $U$-values of the building envelope of $0.1 \mathrm{~W} / \mathrm{m}^{2} \mathrm{~K}$ are graphically presented in Figure 8.

The findings for both of the above locations are essentially different than those for Helsinki and Munich with almost opposite result data. As the energy need for heating $\left(Q_{h}\right)$ is estimated to be extremely low, it can be neglected and consequently exempt from further detailed analysis. The findings relative to the total energy need $\left(Q_{\text {total }}\right)$ thus depend basically on findings on cooling $\left(Q_{c}\right)$. The functions behaviour for the analysed energy demand $\left(Q_{h}, Q_{c}\right.$ and $\left.Q_{\text {total }}\right)$ for Athens and Madrid according to the increasing aspect ratio is very similar, only the absolute values are slightly different owing to a small temperature difference between both cities (the city of Athens is a little warmer in the heating and cooling periods with a much shorter heating period, Table 1). 
Helsinki $\left(U_{\text {wall }}=0.10 \mathrm{~W} / \mathrm{m}^{2} \mathrm{~K}\right)$

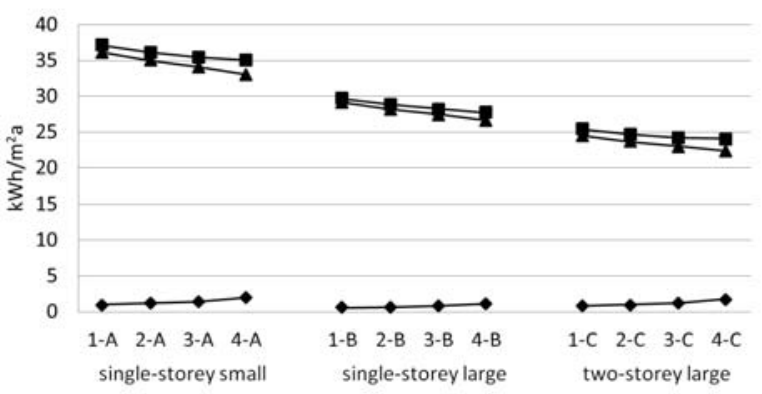

Munich $\left(U_{\text {wall }}=0.10 \mathrm{~W} / \mathrm{m}^{2} \mathrm{~K}\right)$

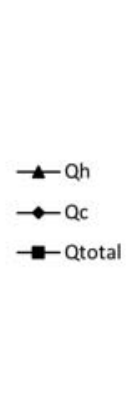

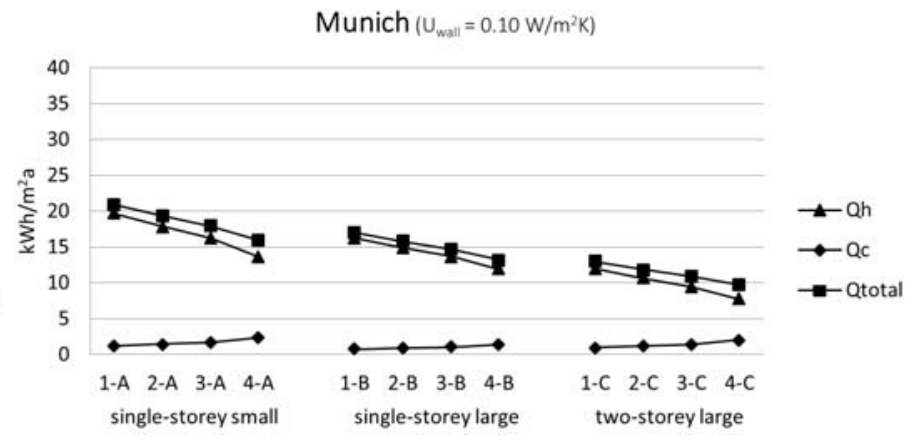

Figure 7: Calculated results for the heating (Qh), cooling (Qc) and total annual energy need (Qtotal) for Helsinki and Munich; Uwall $=0.10 \mathrm{~W} / \mathrm{m}^{2} \mathrm{~K}$, Uroof $=0.10 \mathrm{~W} / \mathrm{m}^{2} \mathrm{~K}$, Ufloor $=0.135 \mathrm{~W} / \mathrm{m}^{2} \mathrm{~K}$

Athens $\left(U_{\text {wall }}=0.10 \mathrm{~W} / \mathrm{m}^{2} \mathrm{~K}\right)$

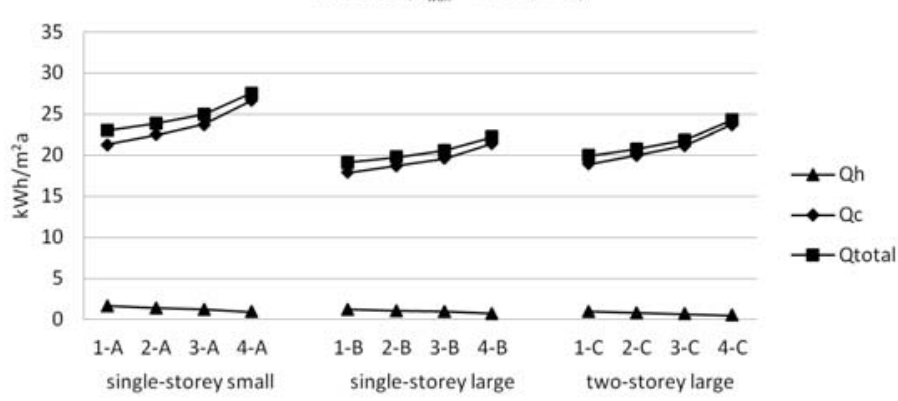

Madrid $\left(\mathrm{U}_{\text {wall }}=0.10 \mathrm{~W} / \mathrm{m}^{2} \mathrm{~K}\right)$

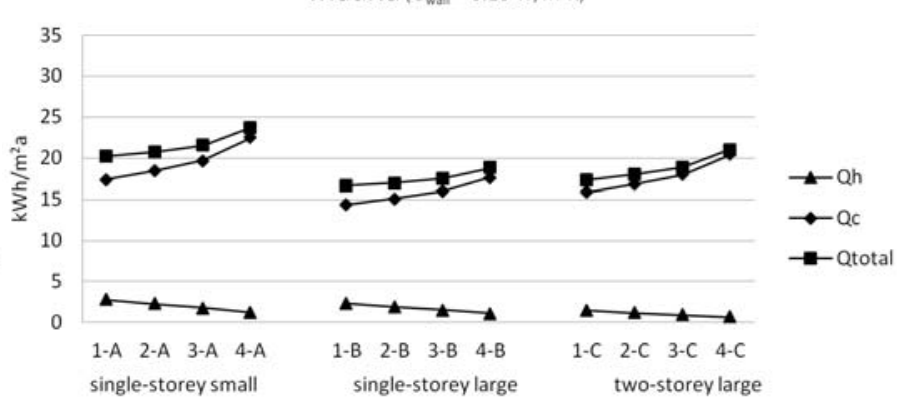

Figure 8: Calculated results for the heating $\left(Q_{h}\right)$, cooling $\left(Q_{d}\right)$ and total annual energy need $\left(Q_{\text {total }}\right)$ for Athens and Madrid; Uwall $=0.10 \mathrm{~W} / \mathrm{m}^{2} \mathrm{~K}$, Uroof $=0.10 \mathrm{~W} / \mathrm{m}^{2} \mathrm{~K}$, Ufloor $=0.135 \mathrm{~W} / \mathrm{m}^{2} \mathrm{~K}$

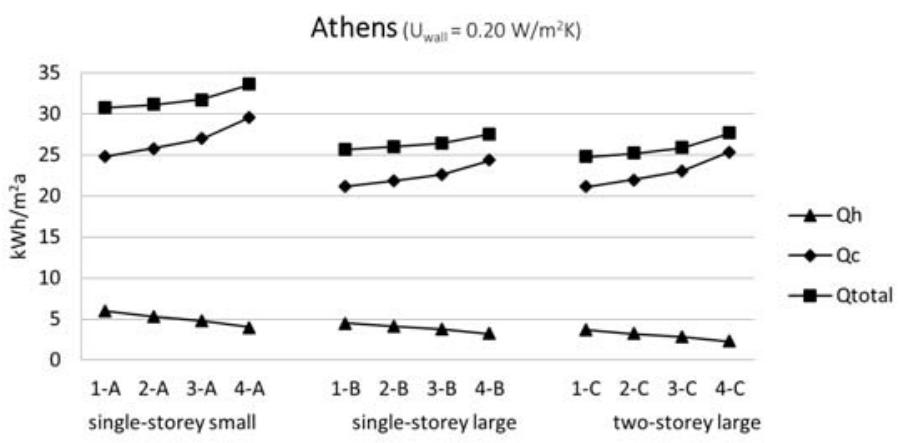

Figure 9: Calculated results for the heating $\left(Q_{h}\right)$, cooling $\left(Q_{d}\right)$ and total annual energy need $\left(Q_{\text {total }}\right)$ for Athens; Uwall $=0.20 \mathrm{~W} / \mathrm{m}^{2} \mathrm{~K}$, Uroof $=0.20 \mathrm{~W} / \mathrm{m}^{2} \mathrm{~K}$, Ufloor $=0.25 \mathrm{~W} / \mathrm{m}^{2} \mathrm{~K}$

Ljubljana $\left(U_{\text {wall }}=0.10 \mathrm{~W} / \mathrm{m}^{2} \mathrm{~K}\right)$

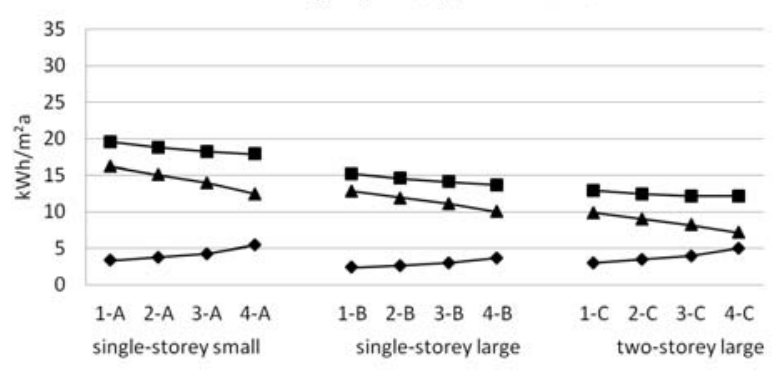

London $\left(U_{\text {wall }}=0.10 \mathrm{~W} / \mathrm{m}^{2} \mathrm{~K}\right)$

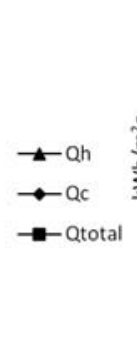

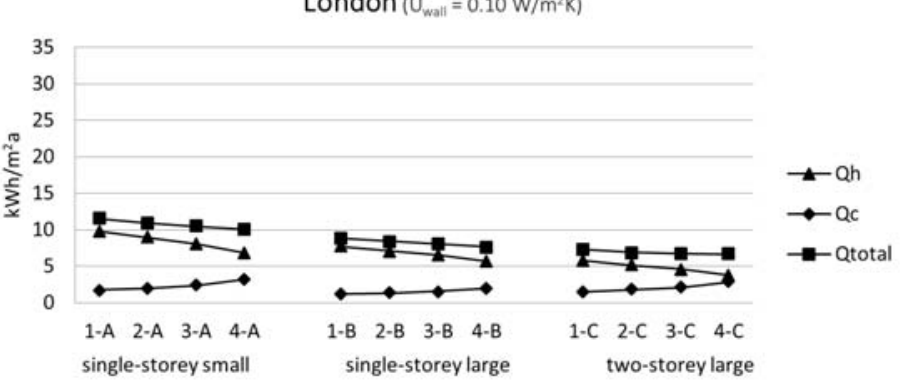

Figure 10: Calculated results for the heating $\left(Q_{n}\right)$, cooling $\left(Q_{d}\right)$ and total annual energy need $\left(Q_{\text {total }}\right)$ for Ljubljana and London 
Thus, it is deduced that the energy need for cooling increases, in an almost exponent dependence, with the increasing aspect ratio (AR). The latter is in correspondence with the enlargement of the glazing size in the south facade as a consequence of the increased length of the south-oriented façade (see glazing areas data in Table 2). A comparison with the results for Helsinki, in particular, brings about a conclusion that the influence of the building-storey is evidently lower for Athens and Madrid. There is a tiny difference between the single-storey building (Model group $B$ ) and the two-storey building (Model group C), with the exception of the model with the highest aspect ratio (Model 4).

Given the fact that the energy need for heating $\left(Q_{h}\right)$ is considerably low, there is no need to design buildings with very low $U$-values of the building envelope for such climate regions. It is more important to prevent overheating of the building. Therefore, the same models for Athens with the highest cooling demand were additionally analysed for $U$-values of $0.20 \mathrm{~W} / \mathrm{m}^{2} \mathrm{~K}, 0.20 \mathrm{~W} / \mathrm{m}^{2} \mathrm{~K}$ and $0.25 \mathrm{~W} / \mathrm{m}^{2} \mathrm{~K}$ for the external walls, roof and basement respectively where the thickness of the thermal insulation is approximately two-times lower than in the models with the $U$-value of $0.10 \mathrm{~W} / \mathrm{m}^{2} \mathrm{~K}$. The results are graphically presented in Figure 9.

Comparing the calculated results with those in Figure 8 we can observe a noticeable increase in the energy need for heating $\left(Q_{h}\right)$, while the cooling energy need $\left(Q_{c}\right)$ increases to a lower extent. Therefore, the difference between $Q_{\text {total }}$ and $Q_{c}$ in all analysed models is now larger than at $U=0.10 \mathrm{~W} / \mathrm{m}^{2} \mathrm{~K}$. Consequently, respecting the total annually energy need, it is interesting to observe that $Q_{\text {tot }}$ (Figure 9) still depends on the aspect ratio, with the influence being slightly weaker than in the case of models with the markedly lower $U$-values of the building envelope (Figure 8). Therefore, the selection of the building envelope composition of an average $U$-value around $0.20 \mathrm{~W} / \mathrm{m}^{2} \mathrm{~K}$ allows designers to apply more flexibility to their planning of the building shape, i.e. creating all possible forms of single or two-storey buildings, with no significant impact on the total energy need.

The conclusions for Ljubljana are equally interesting since the city is located "somewhere in the middle" between Helsinki and Athens. Nevertheless, we have to respect the fact that the city is located on the south side of the Alps and the solar radiation in the heating period is therefore relatively high (see Table 1 ), while the winters tend to be quite long (184 heating days) and relatively cold with an average temperature of $4.50^{\circ} \mathrm{C}$ in the heating period. The results for the low thermal transmittance values of the building envelope $\left(U=0.10 \mathrm{~W} / \mathrm{m}^{2} \mathrm{~K}\right)$ are graphically presented in Figure 10. Due to similar energy behaviour the findings for London are also presented in the figure below.

It can be observed that the functions behaviour for both analysed cities is very similar, only the absolute values are different due to different average temperatures in the heating period $\left(4.5^{\circ} \mathrm{C}\right.$ and $8.3^{\circ} \mathrm{C}$ respectively, Table 1$)$. It can be estimated that the function shapes of the total energy need $\left(Q_{\text {total }}\right)$ for Ljubljana and London are similar to those of Helsinki and Munich, with respect to the fact that the ratio between the energy need for heating $\left(Q_{h}\right)$ and cooling $\left(Q_{c}\right)$ is different. The heating energy need for Ljubljana and London is generally evidently lower than that for Helsinki, while the cooling energy need is much higher and cannot be neglected at all. The increase of the aspect ratio followed by the increase of the glazing surfaces has a favourable impact on the reduction of energy need for heating whilst at the same time it affects the increase of the energy need for cooling. Generally, it can be concluded that the total energy need $\left(Q_{\text {total }}\right)$ decreases with the increasing aspect ratio $(A R)$, in an almost linear way, except for the Model group $C$ where the influence of the increasing aspect ratio is slightly weaker. It is furthermore seen, similarly as for Helsinki, that the total energy need is generally higher for single-storey house models (Model group A) than for two-storey ones (Model group $\mathrm{C}$ ). Comparing only models with the same occupied floor area of $162 \mathrm{~m}^{2}$ brings us to the observation that the two-storey model (Model group $\mathrm{C}$ ) has a slightly lower energy need for heating than the single-storey model (Model group B), with the difference between these two models being lower than in the Helsinki case.

\section{CONCLUSIONS}

It can be generally concluded from the presented study that the building shape (the aspect ratio and the number of floors in this case) can have an important influence on energy behaviour of buildings. It is additionally demonstrated that this influence strongly depends on climate conditions. For Helsinki, the city with the most northern location among the analysed cities, where the total annual energy need mostly consists only of that for heating, the increasing aspect ratio shows a positive influence on the energy need reduction. The latter corresponds well with the findings in [12], where the rectangular shapes with similar aspect ratios (from 1.3 to 1.5 ) were shown to be favourable for cold climates. In our case the aspect ratio for Models » 3 « is 1.21 and for Models »4« 1.69 . Therefore, it is hardly recommended to design buildings with higher/similar aspect ratios. Moreover, the energy need in cold climate conditions is generally higher for the single-storey house than for the two-storey one with the same occupied floor area. The recommendation for cold climate regions therefore is to design buildings with at least two storeys and a higher aspect ratio.

As for the hot climate conditions (Athens and Madrid in our study), the given conclusions are completely different. In this case the findings on the total annual energy need consist mostly of those for cooling, which brings about a conclusion that the energy need increases with the increasing aspect ratio. It is therefore recommendable to design buildings of smaller south façade lengths, similarly as in [11], providing the glazing is placed mainly on the south façade. Moreover, additionally performed 
analysis for Athens with higher Uwall-value confirms that there is no need for using envelope wall elements in much more expensive passive thermal standard $(U=0.10$ $\left.\mathrm{W} / \mathrm{m}^{2} \mathrm{~K}\right)$ when designing buildings for warm climate conditions. The wall elements with a thermal transmittance of around $0.20 \mathrm{~W} / \mathrm{m}^{2} \mathrm{~K}$ allow designers to apply more flexibility to their planning of the building shape, i.e. creating all possible forms of single or two-storey buildings, with no significant impact on the total energy need.

There are still a lot of parameters which have to be analysed. In this study only the case with the south-oriented glazing ratio of $A G A W=35 \%$ is analysed. For hot climate conditions, where the energy need for cooling is decisive, it would be useful to analyse also a similar case with the glazing placed on the northern facade. However, the main output of the current study is to offer architects and civil engineers general information on energy-efficient design for single-family timber-glass buildings under influence of different European climatic conditions and to predict energy behaviour of a building with a simple and fast calculation.

\section{REFERENCES}

1. Diakaki C., Grigoroudis E., Kabelis N., Kolokotsa D., Kalaitzakis K., Stavrakakis G. A multi-objective decision model for the improvement of energy efficiency in buildings. Energy, 2010; 35:5483-5496. https:// doi.org/10.1016/j.energy.2010.05.012

2. Wurm J. Glass Structures - Design and Construction of Self-supporting Skins. Birkhäuser Verlag AG, Basel, Boston, Berlin; 2007.

3. Ian Hsü + Gabriel Rudolphy, SIP m3 House, Chile, 2014.

4. Schlyter + Gezelius Arkitektkontor, Wood House, Sweden, 2010.

5. Architecture Studio Nolla, Hybrid Wooden House, Japan, 2015.

6. Depecker P., Menezo C., Virgone J., Lepers S. Design of building shape and energetic consumption. Building and Environment, 2001; 36(5):627-635. https://doi.org/10.1016/S0360-1323(00)00044-5

7. Albatici R., Passerini, F. Bioclimatic design of buildings considering heating requirements in Italian climatic conditions - A simplified approach. Building and Environment, 2011; 46(8): 1624-1631. https:// doi.org/10.1016/j.buildenv.2011.01.028

8. Ratti C., Baker N., Steemers K. Energy consumption and urban texture. Energy and Buildings, 2005; 37(7): 762-776. https://doi.org/10.1016/j.enbuild.2004.10.010

9. Danielski I., Fröling M., Joelsson A. The Impact of the Shape Factor on Final Energy Demand in Residential Buildings in Nordic Climates, Conference: World Renewable Energy Forum, WREF 2012, Including World Renewable Energy Congress XII and Colorado Renewable Energy Society (CRES) Annual Conference, Volume 6; 2012.
10. Rodrigues E., Amaral A. R., Rodrigues Gaspar A., Gomes A., How reliable are geometry-based building indices as thermal performance indicators?, Energy Conversion and Management, Volume 101, 1 September 2015, Pages 561-578, ISSN 0196-8904. https://doi.org/10.1016/j.enconman.2015.06.011

11. Ling, C.S., Ahmad, M.H., Ossen, D.R., The effect of geometric shape and building orientation on minimising solar insolation on high-rise buildings in hot humid climate. Journal of Construction in Developing Countries; 2007; 12 (1): 27-38.

12. Inanici N.M., Demirbilek F.N. Thermal performance optimization of building aspect ratio and south window size in five cities having different climatic characteristic of Turkey. Building and Environment, 2000; 35(1):41-52. https://doi.org/10.1016/S03601323(99)00002-5

13. Chiras D. The Solar House: Passive Heating and Cooling. Chelsea Green Publishing, White River Junction, VT.; 2002.

14. Hemsath T. L., Bandhosseini K.A., Sensitivity analysis evaluating basic building geometry's effect on energy use, Renewable Energy, Volume 76, April 2015, Pages 526-538, ISSN 0960-1481. https://doi. org/10.1016/j.renene.2014.11.044

15. Aksoy U. T., Inalli M., Impacts of some building passive design parameters on heating demand for a cold region, Building and Environment 41 (2006) 17421754. https://doi.org/10.1016/j.buildenv.2005.07.011

16. EN ISO 13790:2008(en) ISO 13790:2008(en) Energy performance of buildings - Calculation of energy use for space heating and cooling, International Organization for Standardization; 2008.

17. Premrov, M., Žegarac Leskovar, V., Mihalič, K. Influence of the building shape on the energy performance of timber-glass buildings in different climatic conditions. Energy, 2016; 108: 201-211. https://doi. org/10.1016/j.energy.2015.05.027

18. Szokolay, S. V. Introduction to Architectural Science, The Basis of Sustainable Design, Elsevier, Oxford; 2008.

19. Žegarac Leskovar V., Premrov M. Energy-efficient timber-glass houses. Springer Verlag, 2013.

20. Žegarac Leskovar V., Premrov M. An approach in architectural design of energy-efficient timber buildings with a focus on the optimal glazing size in the south-oriented façade. Energy and Buildings, 2011; 43(12):3410-3418. https://doi.org/10.1016/j.enbuild.2011.09.003

21. PHPP 8 - Passive house design package.

22. Meteonorm Software, Meteotest, Bern Switzerland.

Paper submitted: 10.05.2017.

Paper accepted: 22.10.2017.

This is an open access article distributed under the CC BY-NC-ND 4.0 terms and conditions. 